\title{
Overexpression of E2F-5 correlates with a pathological basal phenotype and a worse clinical outcome
}

\author{
S Umemura*,', M Shirane ${ }^{2}$, S Takekoshi', T Kusakabe', J Itoh ${ }^{3}$, N Egashira', Y Tokuda ${ }^{4}$, K Mori $^{2}$ and \\ YR Osamura'
}

'Department of Pathology, Tokai University School of Medicine, Isehara, Japan; ${ }^{2}$ Product Research, Chugai Pharmaceuticals Co. Ltd, Kamakura, Japan; ${ }^{3}$ Laboratory of Structure and Function Research, Tokai University School of Medicine, Isehara, Japan; ${ }^{4}$ Department of Surgery, Tokai University School of Medicine, Isehara, Japan

The purpose of the present study is to identify genes that contribute to cell proliferation or differentiation of breast cancers independent of signalling through the oestrogen receptor (ER) or human epidermal growth factor receptor 2 (HER2). An oligonucleotide microarray assayed 40 tumour samples from $\operatorname{ER}(+) / \mathrm{HER} 2(-), \mathrm{ER}(+) / \mathrm{HER} 2(+), \mathrm{ER}(-) / \mathrm{HER} 2(+)$, and $\mathrm{ER}(-) /$ HER2(-) breast cancer tissues. Quantitative reverse transcriptase PCR detected overexpression of a cell cycle-related transcription factor, E2F-5, in ER-negative breast cancers, and fluorescence in situ hybridisation detected gene amplification of E2F-5 in 5 out of 57 (8.8\%) breast cancer samples. No point mutations were found in the DNA-binding or DNA-dimerisation domain of E2F-5. Immunohistochemically, E2F-5-positive cancers correlated with a higher Ki-67 labelling index $(59.5 \%, P=0.00 \mathrm{I})$ and higher histological grades $(P=0.049)$. E2F-5-positive cancers were found more frequently in $E R(-) /$ progesterone receptor $(P g R)(-) /$ HER2 $(-)$ cancer samples $(51.9 \%, P=0.0049)$ and in breast cancer samples exhibiting a basal phenotype $(56.0 \%, P=0.0012)$. Disease-free survival in node-negative patients with E2F-5-positive cancers was shorter than for patients with E2F-5-negative cancers. In conclusion, we identify, for the first time, a population of breast cancer cells that overexpress the cell cycle-related transcription factor, E2F-5. This E2F-5-positive breast cancer subtype was associated with an ER(-)/PgR(-)/HER2(-) status, a basal phenotype, and a worse clinical outcome.

British Journal of Cancer (2009) I 00, 764-77I. doi:10.1038/sj.bjc.6604900 www.bjcancer.com

(C) 2009 Cancer Research UK

Keywords: breast cancer; oestrogen receptor; HER2; E2F-5; transcription factor

Oestrogen plays a major role in the mammary gland for duct elongation and branching, and also accelerates proliferation of epithelial cells. Responsiveness to oestrogen is retained after carcinogenesis in approximately $70 \%$ of all breast cancers. Mitogenic effects of oestrogens have been explained by two different mechanisms (Gaben et al, 2004). Oestrogen can induce genomic effects through oestrogen-responsive elements located in the promoter region of c-fos (Weisz and Rosales, 1990) and/or c-myc (Dubik and Shiu, 1992) to affect mitogenic activity involving G1 phase progression, and oestrogen can also mediate indirect effects on cyclin D1 gene transcription (Sabbah et al, 1999). Regulation of cyclin D1 gene transcription is strictly regulated in a hormone-dependant manner, and correspondingly, the cAMP response element in the promoter region of the cyclin D1 gene requires interaction with the AF-1 and AF-2 domains of oestrogen receptor (ER) $\alpha$. Other non-genomic actions of oestrogen through mitogen-activated protein kinase/extracellular signal-regulated kinase (ERK) and PI-3K/Akt signalling pathways have been debated (Gaben et al, 2004). The effects of oestrogen binding to ERs represent a major target in the development of novel drugs and therapeutic strategies. Currently, adjuvant endocrine therapies

*Correspondence: Dr S Umemura, Department of Pathology, Tokai University School of Medicine, Shimokasuya 143, Isehara, Kanagawa 259-

I 193, Japan; E-mail: umemura@is.icc.u-tokai.ac.jp

Revised 24 November 2008; accepted 4 January 2009 are primarily based on targeting expression of hormone receptors (Goldhirsch et al, 2007).

Human epidermal growth factor receptor-2 (HER2) is a tyrosine kinase receptor, well characterised for its role in breast cancer. Specific ligands for HER2 have not been identified; however, dimer formation involving HER2, for example, a homodimer of HER2 or a HER2-HER3 heterodimer, have been shown to strongly activate intracellular signalling for cell proliferation, survival, motility, and adhesion (Ross et al, 2004). Two major signalling pathways used by HER family receptors are the Raf/MEK/ERK pathway and the PI3K/PDK1/Akt pathway (Navolanic et al, 2003). Downstream signalling from these pathways can affect regulation of gene expression to promote cell-cycle progression through inhibition of p27 (Medema et al, 2000; Delmas et al, 2001) and activation of cyclin D1 (Cheng et al, 1998), or by inhibition of apoptosis through phosphorylation of Bad and caspase 9 (Cardone et al, 1998). Human epidermal growth factor receptor-2 gene amplification is a poor prognostic factor in breast cancer (Slamon et al, 1987) and plays an important role in resistance to hormone therapy and polychemotherapy experienced by HER2-positive cancer patients. However, HER2 gene amplification is predictive of a positive response to doxorubicin (Paik et al, 1998) and trastuzumab (a humanised anti-HER2 antibody) (Gaskell et al, 1992; Cobleigh et al, 1999; Slamon et al, 2001; Vogel et al, 2002).

In contrast to ER-positive or HER2-positive breast cancers, mechanisms of cell proliferation and differentiation in breast cancers lacking ER and HER2 (ER(-)/HER2(-)) have not been 
well characterised. A hierarchical clustering study of gene expression by Sorlie et al $(2001,2003)$ showed that breast cancers can be clustered into four subtypes: luminal, HER2-positive, basallike, and normal breast-like, based on their expression patterns of ER, HER2, cytokeratin (CK)5/6, and other markers. The basal-like subtype is characterised by an absence of detectable ER and HER2 expression combined with positive expression of vimentin, epidermal growth factor receptor (EGFR), CK8/18, and CK5/6 (Livasy et al, 2006). Tough 'basal-like subtype' was an originally genotypic concept; increasing studies have refined the 'basal-like subtype' as breast cancers with immunophenotype of ER/ progesterone receptor (PgR)/HER2-negative breast cancers (triplenegative breast cancer; TNBC) and also positive for EGFR and/or CK5/6 expression (Carey et al, 2006). On the other hand, TNBC expresses a basal phenotype in $56.0 \%$ of cases compared with nonTNBC (11.5\%) (Rakha et al, 2007). Thus, the relationship between breast cancers with a basal phenotype and TNBC has been identified. However, it is not fully understood how carcinoma cells can proliferate independent from ER or HER2 signalling pathways. This study focused on identifying molecules associated with cell proliferation or differentiation in ER-negative and HER2-negative breast cancers using oligonucleotide microarrays, quantitative reverse transcriptase-PCR ( $\mathrm{qRT}-\mathrm{PCR}$ ), and genetic alteration studies including mutation analysis and fluorescence in situ hybridisation (FISH).

\section{MATERIALS AND METHODS}

\section{Patients and tumour samples}

A total of 40 samples, including 39 invasive ductal carcinomas and one ductal carcinoma in situ, were derived from immunohistochemically determined $\operatorname{ER}(+) / \operatorname{HER} 2(-), \quad \operatorname{ER}(+) / \operatorname{HER} 2(+)$, $\operatorname{ER}(-) / \operatorname{HER} 2(+)$, and ER( $(-) / \operatorname{HER} 2(-)$ tissue types. None of the patients providing the samples had received any pre-operative adjuvant hormone therapy or chemotherapy, and the patients were informed of the privacy policy of the study. The study design was approved by an institutional ethics committee. The incidence of the four immunohistochemistry (IHC) phenotypes were 6.9\% $\operatorname{ER}(+) / \operatorname{HER} 2(+), 8.6 \% \quad \mathrm{ER}(-) / \mathrm{HER} 2(-), \quad 14.8 \% \mathrm{ER}(-) /$ HER2 $(+)$, and $69.7 \% \operatorname{ER}(+) / \operatorname{HER} 2(-)$. Ten samples from each category were serially collected, snap frozen in liquid nitrogen, and stored at $-80^{\circ} \mathrm{C}$ for microarray analysis. The remaining breast cancer samples were fixed in $10 \%$ formalin incubated within $48 \mathrm{~h}$, embedded in paraffin, and subjected to immunohistochemical analysis as described below.

For analysis of E2F-5 expression, tumour samples of ER(-)/ HER2 (-) cancers were collected serially. In addition to 15 samples submitted for microarray analysis, which included $4 \mathrm{ER}(+) /$ $\operatorname{HER} 2(-), 4 \mathrm{ER}(+) / \operatorname{HER} 2(+), 3 \mathrm{ER}(-) / \operatorname{HER} 2(+)$, and $4 \mathrm{ER}(-) /$ HER2 $(-)$ tissue samples, $15 \operatorname{ER}(-) / \operatorname{HER} 2(-)$ cancers and 13 control samples (2 non-neoplastic mammary gland and 11 blood samples) were submitted for mutation analysis (43 total samples). For clinical and pathological analysis of E2F-5 expression, FISH and IHC assays were performed on 17 ER(-)/HER2(-) breast cancer samples in addition to 10 samples from each of the 4 breast cancer subtypes analysed by oligonucleotide microarray (57 total samples).

\section{Microarray analysis}

Total RNA was isolated by phenol-chloroform extraction (Sepazol-I, Wako, Japan) from 100-200 mg of fresh frozen tissue. The extracted RNA was reverse transcribed to cDNA using T7oligo-dT primer (synthesised by Qiagen Inc., Valencia, CA, USA) and converted to double-stranded DNA, which was used for synthesis of biotin-labelled cRNA using the MEGAscript In Vitro
Transcript Kit (Ambion, Austin, TX, USA). The cRNA was fragmented and hybridised to oligonucleotide microarray chips (GeneChip ${ }^{\circledR}$ U95Av2, Affymetrix, Santa Clara, CA, USA), which contained 12558 genes. Probe arrays were stained with streptavidin-phycoerythrin (Molecular Probes Inc., Eugene, OR, USA) and scanned. The intensity of each signal was captured with Affymetrix GeneChip Expression Analysis Software (LIMS5.0) according to Affymetrix's standard procedures, and was analysed with Excel (Microsoft Corp., Mountain View, CA, USA).

Gene expression data were log-transformed for further analysis. From the 7559 genes that were expressed at detectable levels in at least 3 samples, 831 genes with a coefficient of variation (standard deviation/mean) $>0.1$ were identified as genes with significant variation in expression between different tumour types. The 831 genes were analysed by hierarchical cluster analysis using the software, Cluster (http://rana.lbl.gov/EisenSoftware.htm). Significant differential expression was defined as having a two-fold higher or lower change in expression level detected by IHC in ER(-)/HER2(-) tissue samples compared with other tumour subtypes, and IHC data were analysed using Welch's $t$-test and multistep two-way analysis of variance.

\section{Quantative reverse transcriptase PCR (qRT-PCR)}

Total RNA was isolated from frozen samples using Trizol reagent (Invitrogen, Carlsbad, CA, USA). The integrity of the RNA was verified by electrophoresis. The first-strand cDNA was synthesised using SuperScript III First-Strand Synthesis System (Invitrogen). cDNA was subjected to real-time PCR analysis in an ABI PRISM 7700 Sequence Detector (Applied Biosystems Inc., Foster City, CA, USA) using the TaqMan approach. Sets of primers and fluorogenic probes specific for E2F5 were purchased from Applied Biosystems Inc. (Assay on Demand, Hs00231092_m1). The relative amount of target gene present was calculated based on the expression of human beta-actin representing an endogenous control (Applied Biosystems Inc.). Fluorescence was quantified by sequence detection system software (SDS, version 2.0, Applied Biosystems Inc.). Mean cycle threshold values $(\mathrm{Ct})$ and standard deviation (s.d.) were calculated for E2F-5. The amount of target gene was normalised relative to the amount of the beta-actin $[\Delta \mathrm{Ct}=$ $\left.\Delta \mathrm{Ct}_{(\mathrm{E} 2 \mathrm{~F}-5)}-\Delta \mathrm{Ct}_{(\text {beta-actin })}\right]$ and the s.d. calculated [s.d. $(\Delta \mathrm{Ct})=$ $\left.\sqrt{ }\left(\mathrm{SD}_{\mathrm{E} 2 \mathrm{~F}-5}\right)^{2}+(\text { s.d. beta-actin })^{2}\right]$. The factor difference was also calculated $\left(2^{-\Delta \mathrm{Ct}}\right)$. To calibrate the analysis, the value obtained from a non-neoplastic mammary gland was used as a control.

\section{Direct sequencing}

The cDNA for direct sequencing was synthesised from isolated total RNA as described above. Sequencing was performed on both strands. Specific primers were designed to amplify a full length E2F5 cDNA (primer 1 for exon 2-6, forward 5'-AGTGGAAA GGTGTAGGTGC-3', reverse 5'-CTGGATTTCTGTGGAGTCAC-3'; primer 2 for exon 3-8, forward $5^{\prime}$-AATGGTGATACACTTTTGG C- $3^{\prime}$, reverse $5^{\prime}$-GAAGAACACTTCAGAATCAGTG-3'). Polymerase chain reactions were performed with $1 \mathrm{U}$ HotStar Taq DNA polymerase (QIAGEN K.K., Tokyo, Japan) per $20 \mu$ l. Polymerase chain reactions products were separated on an agarose gel, extracted, then run on an ABI 3100 Genetic Analyzer (Applied Biosystems Inc.). The results were analysed using DNASIS ${ }^{\circledR}$ Pro (Hitachi Software Engineering Co. Ltd, Tokyo, Japan).

\section{Fluorescence in situ hybridisation}

An E2F-5 FISH probe was designed to hybridise to chromosome 8 (Supplementary Figure 1) and bacterial artificial chromosome clone PR11-219B4 was obtained from BACPAC Resources (Children's Hospital Oakland Research Institute, Oakland, CA, 
USA). Bacterial artificial chromosome DNA was isolated using a Large-Construct kit (Qiagen Inc.) and labelled using a Nick Translation kit and Spectrum Orange dUTPs (Abbott Molecular Inc., Des Plaines, IL, USA). Fluorescence in situ hybridisation was performed using a centromere 8 (CEP8) DNA probe kit (Abbott Molecular Inc.) in combination with an E2F-5 probe according to the manufacturer's protocol. Signal numbers for the E2F-5 gene (labelled with SpectrumOrange) and CEP8 gene (labelled with SpectrumGreen) were counted in 60 carcinoma cells and plotted. An E2F-5/CEP8 signal ratio $>2.0$ was interpreted as positive.

\section{Immunohistochemistry and pathological evaluation}

Oestrogen receptor expression was stained using an automated machine (Benchmark, Ventana Japan, Yokohama, Japan), and HER2 expression was detected using a kit for HER2 (DAKO HercepTest, DakoCytomation, Carpinteria, CA, USA) in accordance with the manufacturer's instructions and the use of positive and negative controls. Antibodies used included anti-Ki-67 (clone MIB-1, DakoCytomation), anti-E2F-5 (polyclonal, Santa Cruz Biotechnology, Santa Cruz, CA, USA), anti-EGFR (clone 2-18C9, EGFR pharmDxKit, DakoCytomation), and anti-CK5/6 (Clone D5/ 16B4, DakoCytomation). Specificity of the anti-E2F-5 antibody was confirmed using an E2F-5 blocking peptide (SC-999 P, Santa Cruz Biotechnology) and by a single band at $59 \mathrm{kDa}$ detected by immunoblotting. Immunohistochemical evaluation for HER2 was according to the manufacturer's recommendation. Oestrogen receptor and $\mathrm{PgR}$ were evaluated as positive with positive cells more than 10\%, and EGFR and E2F-5 were evaluated as positive with any positive cells. Non-neoplastic tissues examined for E2F-5 expression included gastrointestinal organs, lung, kidney, ovary, uterus, prostate, testes, and brain. All of the samples were pathologically examined according to World Health Organization classification standards (Tavassoli and Devilee, 2003) and the Scarff-Bloom-Richardson grading system (Elston and Ellis, 1991). Breast cancers that were negative for expression of ER, $\mathrm{PgR}$, and HER2 were determined to be 'TNBC'. Alternatively, breast cancer samples lacking expression of ER, PgR, and HER2, while expressing EGFR and/or CK5/6, were considered to have a 'basal phenotype' (Carey et al, 2006).

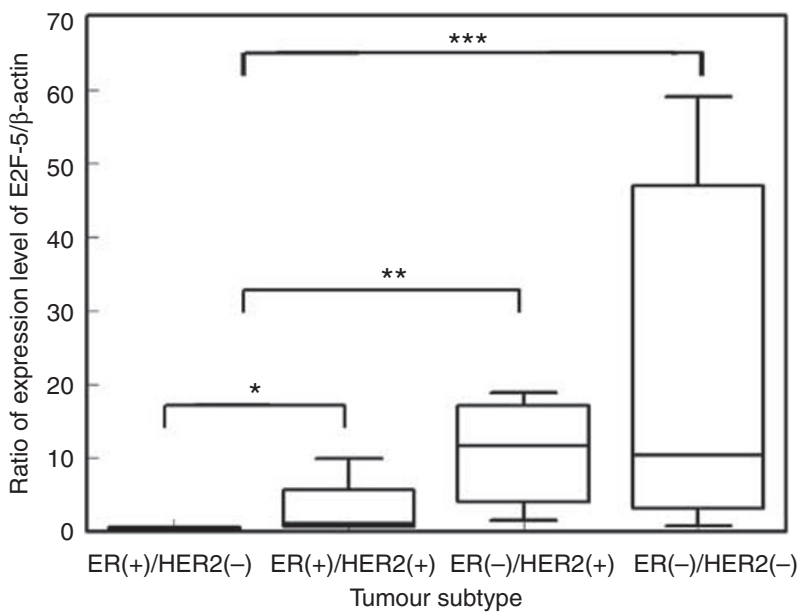

Figure I Quantification of E2F-5 mRNA levels by real-time RT-PCR. The expression level of E2F-5 is gradually higher in $\operatorname{ER}(+) / \mathrm{HER} 2(-)$, $\operatorname{ER}(+) / \operatorname{HER} 2(+), \operatorname{ER}(-) / \operatorname{HER} 2(+)$, and $\operatorname{ER}(-) / \operatorname{HER} 2(-)$ breast cancer subtypes, respectively. $* P=0.02$ for $\operatorname{ER}(+) / \mathrm{HER} 2(-)$ vs $\mathrm{ER}(+) /$ $\operatorname{HER} 2(+) ; * * P=0.02$ for $\operatorname{ER}(+)$ vs $\operatorname{ER}(-) / \operatorname{HER} 2(+)$; $* * * P=0.04$ for $\mathrm{ER}(+) / \mathrm{HER} 2(+)$ vs $\mathrm{ER}(-) / \mathrm{HER} 2(-)$.

\section{Statistical analysis}

The $\chi^{2}$-test was used to evaluate the significance of clinicopathological characteristics compared between E2F-5-positive and -negative breast cancers with lymph node metastasis. The $\chi^{2}$-test was also used to analyse the immunohistochemical profiles of ER and HER2 expression. The Kruskal-Wallis test was used for data from tumour size and histological grade, and the Mann-Whitney test was used for data from Ki-67 labelling. Kaplan-Meier curves were used in survival analysis and the log-rank test was used for assessment of differences among multiple survival curves.

\section{RESULTS}

\section{Genes differentially expressed in ER-negative/HER2- negative breast cancer samples}

In all, 17 genes differed in expression between the ER(-)/HER2(-) samples and the other breast cancer subtypes analysed (i.e. $\operatorname{ER}(+) / \operatorname{HER} 2(-), \quad \operatorname{ER}(+) / \operatorname{HER} 2(+)$, and $\operatorname{ER}(-) / \operatorname{HER} 2(+))$. Eight genes were overexpressed (FABP7, GABRP, GAL, CXCL13, CDC42EP4, C2F, FOXM1, and CSDA), whereas nine genes showed decreased expression (ITGB5, KIAA0310, MAGED2, PRSS11,

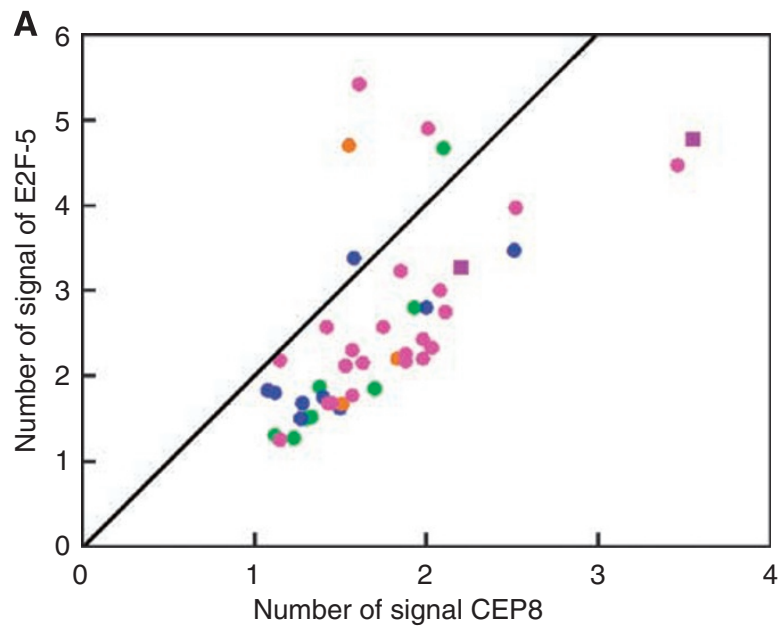

B

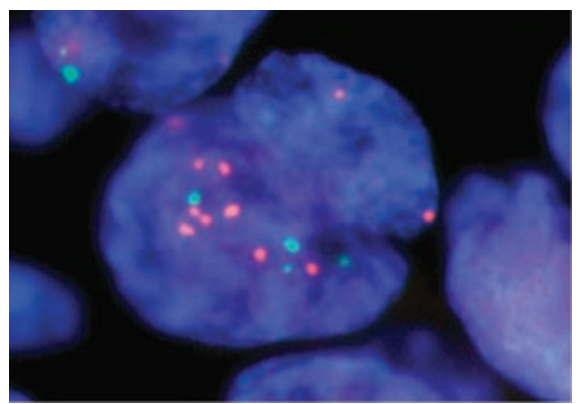

Figure 2 Labelling of centromere 8 and E2F-5 by fluorescence in situ hybridisation (FISH). (A) The number of CEP8 and E2F-5 signals from the FISH experiments are plotted on the $x$ - and $y$-axis, respectively. Five tumours, plotted on the upper left side of the solid line, have an E2F-5/ CEP8 signal ratio of $>2$ and are therefore predicted to have undergone E2F-5 gene amplification. Data from the various breast cancer samples are labelled in the figure as follows: green circle dots - ER $(+) / \mathrm{HER} 2(-)$; blue circle dots - ER $(+) / H E R 2(+)$; orange circle dots - ER $(-) / H E R 2(+)$; pink circle dots $-E R(-) / H E R 2(-)$. Data from breast cancer cell lines (MCF-7, MDA-MB23I) are indicated with purple square dots. (B) Centeromere 8 (CEP8) is labelled in green and E2F-5 is labelled in orange in ER(-)/ HER2(-) cells. 


\section{BJC $\cap$}

SORL1, TGFB3, KRT18, CPE, and BCAS1). None of the genes identified were directly related to cell proliferation proteins, such as cyclins, cyclin-dependant kinases, p53, p16, and the pRb and p21 families. When the candidate genes and their expression profiles for the ER(-)/HER2(-) samples and the ER-positive breast cancer samples, including $\operatorname{ER}(+) / \operatorname{HER} 2(-)$ and $\operatorname{ER}(+) /$ HER2 $(+)$ were compared, a subset of proteins were found to be overexpressed (CDKN2A (p16), E2F5, and CDC20), while CCND1 and GATA3 exhibited decreased expression in ER(-)/HER2(-) breast cancers (Supplementary Table 1). One of the genes overexpressed in ER(-)/HER2 (-) breast cancer tissues was a cell cycle-related transcription factor, E2F-5. Overexpression of E2F-5 was confirmed at the mRNA level by qRT-PCR (Figure 1). In addition, the expression level of E2F-5 significantly correlated with the level of Ki-67 expression only in ER(-)/HER2(-) samples (data not shown). The biological and clinicopathological significance of the role of E2F-5 in breast cancer has not been addressed earlier; therefore, we further investigated the role of E2F-5 in breast cancer.

\section{E2F-5 gene amplification in breast cancers}

Gene amplification of E2F-5 was examined by FISH. The mean signal numbers of CEP8 and E2F-5 were calculated and their ratio plotted (Figure 2A). Aneusomy of chromosome 8 was more frequent in $\operatorname{ER}(-) / \operatorname{HER} 2(-)$ breast cancers, and CEP8 had an increased signal number in ER(-)/HER2(-) breast cancers (2.0) compared with $\mathrm{ER}(+)$ breast cancers (1.51). E2F-5 gene amplification (E2F-5/CEP8 >2.0) was detected in five breast cancer samples: two $\operatorname{ER}(-) / \operatorname{HER} 2(-)$, one $\operatorname{ER}(+) / \operatorname{HER} 2(-)$, one $\operatorname{ER}(+) / \operatorname{HER} 2(+)$, and one $\operatorname{ER}(-) / \operatorname{HER} 2(+)$. An example of E2F-5 gene amplification in a ER(-)/HER2(-) breast cancer sample is shown in Figure 2B.

\section{Intracytoplasmic localisation of E2F-5 in normal tissues and breast cancers}

Immunohistochemical studies detected E2F-5 in the cytoplasm of various epithelial and non-epithelial cells. E2F-5 was expressed in the smooth muscle cells of blood vessels and the intestinal wall, as well as in chondrocytes of the bronchial wall, in epithelial cells of the mucosal epithelium (stomach, colon, pancreatic duct, and gallbladder), in the squamous epithelium (skin and esophagus) (Figure 3A), and in hepatocyte and tubular epithelial cells. Intranuclear localisation of E2F-5 was less frequently detected in cardiomyocyte and smooth muscle cells of the gastrointestinal wall (Figure 3B). In the non-neoplastic mammary gland, a few ductal epithelial cells were positive for cytoplasmic E2F-5 expression

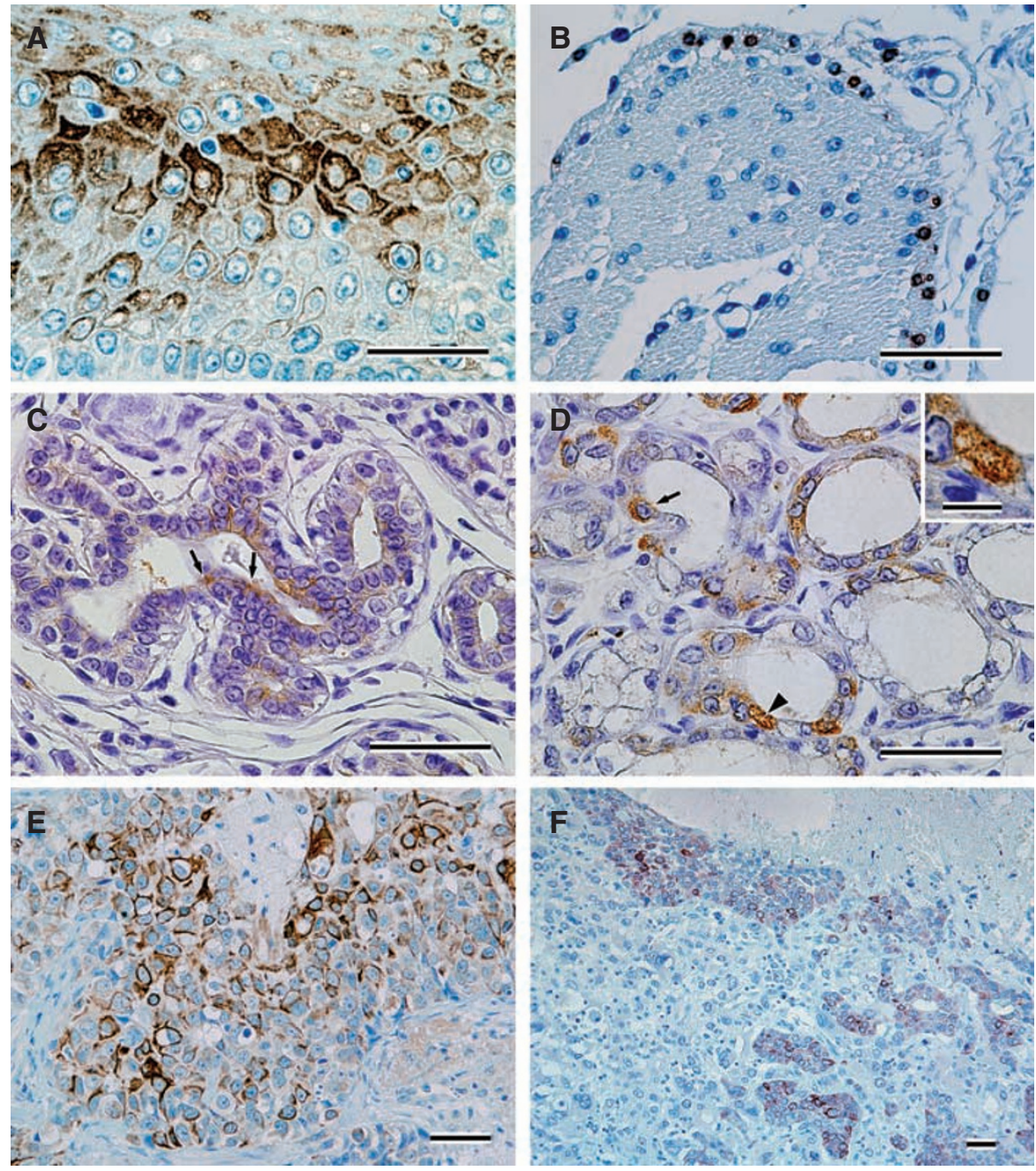

Figure 3 Immunohistochemical study of E2F-5 expression in non-neoplastic and breast cancer tissues. Detection of E2F-5 in (A) squamous epithelium and (B) non-epithelial smooth muscle cells. In non-neoplastic mammary gland tissue, positive cells are detected in a resting state in the cytoplasm (C) as well as in the lactating phases (D) indicated by arrows. An arrow head (D) and inset indicate positive cells in nucleus. E2F-5 is also shown expressed in the cytoplasm of carcinoma cells $(\mathbf{E})$. All of the metaplastic cancers tested were positive for E2F-5 $(\mathbf{F})$. Scale bar indicates a length of $50 \mu \mathrm{m}(\mathbf{A}-\mathbf{F})$ and I0 $\mu \mathrm{m}$ (inset). 
(Figure 3C), whereas in the lactating mammary gland cells with nuclear expression of E2F-5 were detected in addition to cytoplasmic-positive cells (Figure 3D).

In the 19 breast cancer tissues positive for E2F-5, E2F-5 protein was only detected in the cytoplasm (Figure $3 \mathrm{E}$ ), and the number of positive cells varied from tumour to tumour. Two ER(-)/HER2(-) tumour samples with E2F-5 gene amplification were positive for E2F-5, whereas three other tumour types $(\operatorname{ER}(+) / \operatorname{HER} 2(-)$, $\operatorname{ER}(+) / \operatorname{HER} 2(+)$, and $\operatorname{ER}(-) / \operatorname{HER} 2(+))$ with E2F-5 gene amplification were negative for E2F-5.

\section{Mutation analysis of E2F-5}

E2F-5 is a transcription factor lacking a nuclear localisation signal (Dyson, 1998); therefore, transportation of E2F-5 into the nucleus is supported by binding interactions with dimerisation protein (DP) 3 or p130 proteins. We conducted a mutation analysis to determine whether a genetic mutation was present in the region of E2F-5 associated with the binding of transport proteins to affect the intracytoplasmic localisation of E2F-5 protein observed in the breast cancer subtypes. Only a synonymous mutation at codon 44 (GCG to GCC, Ala/Ala) was found in the DNA-binding domain of E2F-5. A polymorphism at this site was detected in 12 out of 13 control samples and in 28 out of 30 breast cancer tissues. Splicing variants with 3-bp deletions between exon 6 and exon 7 were also detected in all of the 13 control samples and the 30 breast cancer samples examined (Supplementary Figure 2).

\section{Clinicopathological characteristics of immunohistochemically E2F-5-positive breast cancers}

We compared clinicopathological characteristics between immunohistochemically determined E2F-5-positive and -negative breast cancer samples (Table 1). There were no significant differences in tumour size, lymph node metastasis, or HER2 expression between these two groups. E2F-5-positive breast cancers exhibited a higher histological grade $(P=0.049)$, were highly ER and PgR negative $(P=0.039, P=0.010$, respectively), and maintained a higher Ki-67 labelling index $(P=0.001)$. Furthermore, we defined samples with negative expression of ER, PgR, and HER2 as 'TNBC' samples, while TNBC samples expressing EGFR and/or CK5/6 were defined as 'basal phenotype' samples. Our analysis showed that E2F-5positive cancers were more frequent in TNBC $(51.9 \%)$ samples than in non-TNBC $(16.7 \%)$ samples $(P=0.0049)$, were more frequent in breast cancer samples exhibiting a basal phenotype $(56.0 \%)$ than in those exhibiting a non-basal phenotype $(15.6 \%)$ $(P=0.0012)$, and were more frequent in metaplastic carcinomas $(P=0.0034)$ (Table 1$)$.

Disease-free survival was extended in patients with nodenegative/E2F-5-negative cancers $(n=23)$ compared with nodenegative/E2F-5-positive samples $(n=15)$, node-positive/E2F-5negative samples $(n=13)$, and node-positive/E2F-5-positive samples $(n=6)$ (Figure $4, P=0.014)$. In addition, in the lymph node-negative group, the E2F-5-positive subset exhibited a shorter disease-free survival period $(n=13, P=0.013)$ than the E2F-5negative group $(n=23)$. There were no significant differences between ER-positive $(n=12)$ and -negative groups $(n=24$, $P=0.14)$, or between HER2-positive $(n=10)$ and -negative groups $(n=26, P=0.22)$.

\section{DISCUSSION}

This study has identified a subpopulation of breast cancer cells that overexpress the transcription factor E2F-5. We found E2F-5positive breast cancers were more frequent in TNBC samples and also in samples exhibiting a basal phenotype with higher Ki-67 labelling indexes. Patients with node-negative/E2F-5-positive
Table I Clinicopathological features of E2F-5-positive breast cancers

\begin{tabular}{|c|c|c|c|}
\hline & \multicolumn{3}{|c|}{ E2F-5 } \\
\hline & $\begin{array}{c}\text { Positive } \\
n=19\end{array}$ & $\begin{array}{c}\text { Negative } \\
n=38\end{array}$ & $P$-value \\
\hline Tumour size & & & NS \\
\hline $\mathrm{TI}$ & 9 & 17 & \\
\hline $\mathrm{T} 2$ & 7 & 14 & \\
\hline T3 & 3 & 6 & \\
\hline Lymph node metastasis & & & NS \\
\hline Absent & 6 & 15 & \\
\hline Present & 13 & 23 & \\
\hline Histological grade & & & 0.049 \\
\hline 1 & 0 & 6 & \\
\hline$\|$ & 6 & 21 & \\
\hline III & 13 & 11 & \\
\hline Oestrogen receptor & & & 0.039 \\
\hline Positive & 3 & 16 & \\
\hline Negative & 16 & 22 & \\
\hline Progesterone receptor & & & 0.010 \\
\hline Positive & 2 & 17 & \\
\hline Negative & 17 & 21 & \\
\hline HER2 & & & NS \\
\hline Positive & 5 & 14 & \\
\hline Negative & 14 & 24 & \\
\hline Pathological characteristics & & & \\
\hline TNBC & 14 & 13 & 0.0049 \\
\hline Non-TNBC & 5 & 25 & \\
\hline Basal phenotype & 14 & 11 & 0.0012 \\
\hline Non-basal phenotype & 5 & 27 & \\
\hline Apocrine carcinoma & I & 3 & NS \\
\hline Metaplastic carcinoma & 4 & 0 & 0.0034 \\
\hline Ki-67 labelling index (\%) & $59.5 \pm 20.4$ & $36.3 \pm 26.3$ & 0.001 \\
\hline
\end{tabular}

cancers also showed worse clinical outcomes with shorter disease-free survival periods. The biological and clinicopathological significance of E2F-5 expression in breast cancer has not been well documented, but we show here that overexpression of E2F-5 correlated with aggressive histological pathologies and a worse clinical outcome.

E2F-5 belongs to the E2F transcription factor family, which consists of eight members, E2F-1-8 (La Thangue and Rigby, 1987; Dyson, 1998). On the basis of sequence homology and function, E2F family members have been divided into three distinct groups: E2F-1-3 (Helin et al, 1992; Kaelin et al, 1992; Shan et al, 1992; Ivey-Hoyle et al, 1993; Lees et al, 1993), E2F-4 and 5 (Ginsberg et al, 1994; Hijmans et al, 1995; Sardet et al, 1995), and E2F-6 (Morkel et al, 1997; Cartwright et al, 1998; Trimarchi et al, 1998). Heterodimers formed between E2F-1-3 and DPs have been shown to be strong transcriptional activators that can drive quiescent cells into S phase (Kowalik et al, 1995; DeGregori et al, 1997; Lukas et al, 1997; Verona et al, 1997). In addition, these heterodimers can stimulate the transcription of genes involved in cell-cycle control (cyclin A, cyclin E, pRb, p107, E2F-1), initiation of replication (Orc1, cdc6, MCM3), DNA synthesis (DNA polymerase, thymidylate synthesis, thymidine kinase, dihydrofolate reductase), and can also drive expression of proto-oncogenes (c-myb, B-myb, 

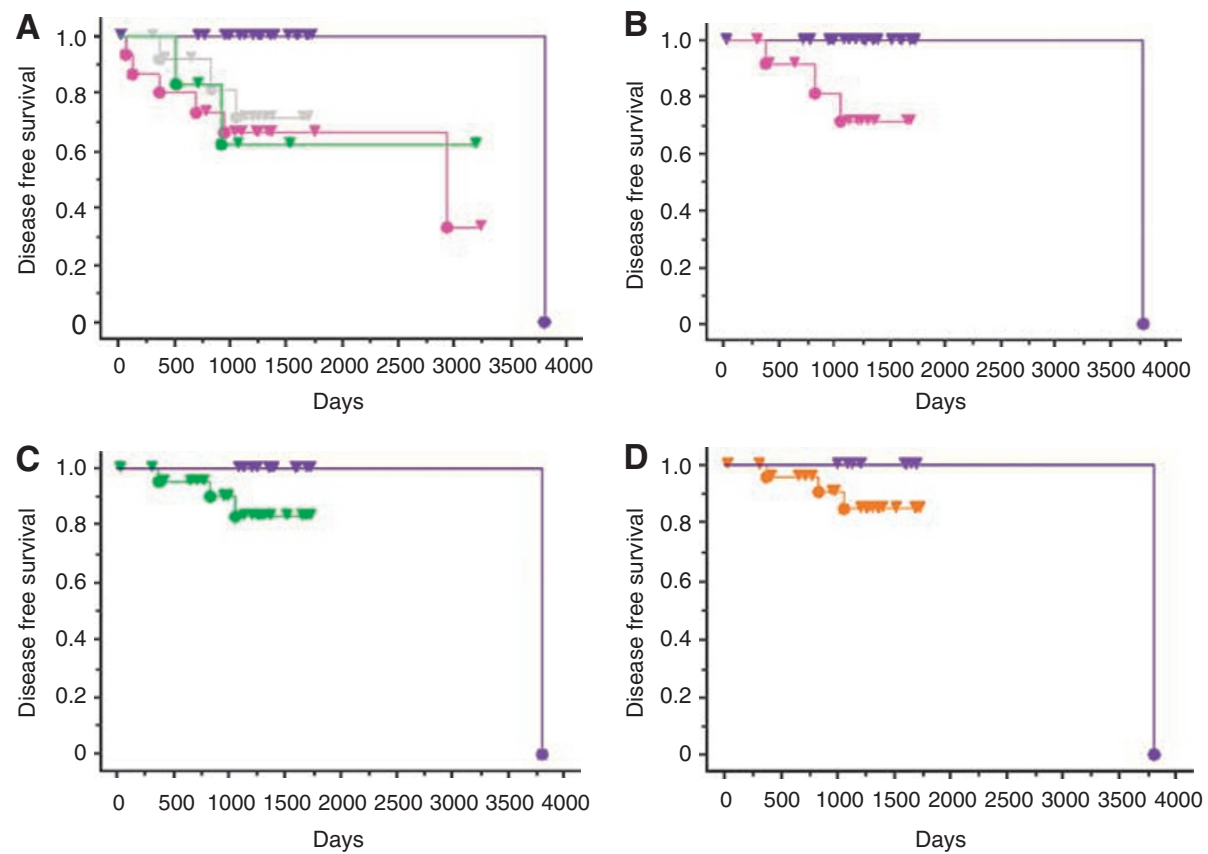

Figure 4 Kaplan-Meier survival analysis for patients with each of the four breast cancer subtypes analysed. (A) Disease-free survival was extended in the node-negative/E2F-5-negative cancer subtypes (blue, $n=23$ ) compared with the node-negative/E2F-5-positive subtype (pink, $n=15$ ), the node-positive/ E2F-5-negative subtype (gray, $n=13$ ), and the node-positive/E2F-5-positive cancer subtype (green, $n=6)(P=0.014)$. In the lymph node-negative subgroup (B-D), the E2F-5 positive group shows a shorter disease-free survival interval (pink, $n=13, P=0.013$ ) than the E2F-5-negative group (blue, $n=23$ ). There were no significant differences between the ER-positive $(\mathbf{C}$; green, $n=12)$ and -negative groups $(\mathbf{C} ;$ blue, $n=24, P=0.14)$, and the HER2-positive $(\mathbf{D}$; orange, $n=10)$ and -negative groups $(\mathbf{D}$; blue, $n=26, P=0.22)$.

c-myc, N-myc) (Campanero et al, 1999; Trimarchi and Lees, 2002). In contrast, the functional roles of E2F-4 and 5 remain to be fully characterised. In studies of homozygous E2F-5 knockout embryos, despite an initial normal phenotype, the newborn mice go on to develop non-obstructive hydrocephalus from excessive production of cerebrospinal fluid. This phenotype supports a role for E2F-5 in differentiation of neural tissue rather than in cell proliferation (Lindeman et al, 1998). In a separate study, murine embryonic fibroblasts derived from E2F-5 knockout mice were shown to proliferate normally and reenter the cell cycle from the G0 phase, but failed to arrest at the G1 phase in response to overexpression of p16 (Lindeman et al, 1998; Gaubatz et al, 2000). When the E2F-5 gene was cotransfected with DP-1 and Ras into baby rat kidney cells, an increased number of transformed foci were induced; thereby, suggesting an oncogenic role for human E2F-5 (Polanowska et al, 2000). The results of our study further indicate that overexpression of E2F-5 correlates with an aggressive pathology of certain breast cancer subtypes.

Gene amplification of E2F-5 was detected in 5 out of 57 (8.8\%) breast cancer samples examined in this study. It was intriguing that gene amplification of E2F-5 was accompanied by E2F-5 protein in ER(-)/HER2(-) breast cancer samples, whereas E2F-5 expression was not detected in other types of cancers that had undergone gene amplification. Although regulatory mechanisms of E2F-5 gene transcription have not been characterised beyond studies of E2F-5 overexpression at the mRNA and protein levels in ER(-)/HER2(-) breast cancers, we hypothesise that additional unknown factors are contributing to the transcription, translation, and gene amplification of E2F-5. Macaluso et al (2003) reported that protein complexes, including $\mathrm{pRb} 2 / \mathrm{p} 130$ and $\mathrm{E} 2 \mathrm{~F}-4 / 5$, can regulate $\mathrm{ER} \alpha$ gene transcription in breast cancer cell lines. Both the relationship between ER expression and the biological role of E2F-
5, as well as the regulatory mechanisms of E2F-5 gene transcription require further investigation.

Although E2F-4 and -5 lack a nuclear localisation signal, they are still able to translocate from the cytoplasm into the nuclei by binding to pocket proteins (p107, p130) and/or DP-1, 2, 3 (Dyson, 1998). E2F-5 has been shown to localise to the cytoplasm in asynchronous cultures of exponentially growing cells, and is recruited into the nucleus of serum-starved cells in a quiescent state (Allen et al, 1997). We also observed localisation of E2F-5 to the nucleus in the G0 phase, whereas E2F-5 localised to the cytoplasm in the other cell-cycle phases (data not shown). If E2F-5 has a functional role in the G0 phase, how then can we explain the detection of a higher Ki-67 index in cells overexpressing E2F-5 in ER(-)/HER2(-) breast cancer samples? We originally hypothesised that intracytoplasmic localisation of E2F-5 in cancer cells was the result of genetic alterations, such as point mutations in the binding site of DP or other pocket proteins, and that dysfunction of E2F-5 could cause increased cell proliferation. However, mutation analysis failed to detect any alteration in amino-acid coding that would affect protein-protein interactions with E2F-5. There are several possible explanations for the accumulation of E2F-5 in the cytoplasm including (1) a failure of the nuclear transporting process or dysfunction of binding interactions between E2F-5 and pocket proteins, and DPs; (2) the inability of cells for G1 arrest of transition into G0 phase; or (3) a failure of E2F-5 to be metabolised through a pathway involving ubiquitination. To determine the role of these possibilities and their associated mechanisms would require further study.

In conclusion, we have shown that a subgroup of breast cancers overexpress a transcriptional factor, E2F-5, and that E2F-5-positive breast cancers were more common in TNBC and in breast cancers 
with a basal phenotype. In addition, these breast cancer subtypes were associated with a worse clinical outcome.

\section{ACKNOWLEDGEMENTS}

We thank Mrs Yukiko Kirimura (Department of Pathology, Tokai University School of Medicine) for technical support for the experiments. Supported by a Grant-in-Aid for Scientific Research (C) (no. 15590317) from the Japanese Society for the Promotion of Science.

\section{REFERENCES}

Allen KE, de la Luna S, Kerkhoven RM, Bernards R, La Thangue NB (1997) Distinct mechanisms of nuclear accumulation regulate the functional consequence of E2F transcription factors. J Cell Sci 110(Pt 22): $2819-2831$

Campanero MR, Armstrong M, Flemington E (1999) Distinct cellular factors regulate the c-myb promoter through its E2F element. Mol Cell Biol 19: $8442-8450$

Cardone MH, Roy N, Stennicke HR, Salvesen GS, Franke TF, Stanbridge E, Frisch S, Reed JC (1998) Regulation of cell death protease caspase-9 by phosphorylation. Science 282: 1318-1321

Carey LA, Perou CM, Livasy CA, Dressler LG, Cowan D, Conway K, Karaca G, Troester MA, Tse CK, Edmiston S, Deming SL, Geradts J, Cheang MC, Nielsen TO, Moorman PG, Earp HS, Millikan RC (2006) Race, breast cancer subtypes, and survival in the Carolina Breast Cancer Study. JAMA 295: 2492-2502

Cartwright P, Muller H, Wagener C, Holm K, Helin K (1998) E2F-6: a novel member of the E2F family is an inhibitor of E2F-dependent transcription. Oncogene 17: 611-623

Cheng M, Sexl V, Sherr CJ, Roussel MF (1998) Assembly of cyclin D-dependent kinase and titration of p27Kip1 regulated by mitogenactivated protein kinase kinase (MEK1). Proc Natl Acad Sci USA 95: 1091 - 1096

Cobleigh MA, Vogel CL, Tripathy D, Robert NJ, Scholl S, Fehrenbacher L, Wolter JM, Paton V, Shak S, Lieberman G, Slamon DJ (1999) Multinational study of the efficacy and safety of humanized anti-HER2 monoclonal antibody in women who have HER2-overexpressing metastatic breast cancer that has progressed after chemotherapy for metastatic disease. J Clin Oncol 17: 2639-2648

DeGregori J, Leone G, Miron A, Jakoi L, Nevins JR (1997) Distinct roles for E2F proteins in cell growth control and apoptosis. Proc Natl Acad Sci USA 94: $7245-7250$

Delmas C, Manenti S, Boudjelal A, Peyssonnaux C, Eychene A, Darbon JM (2001) The p42/p44 mitogen-activated protein kinase activation triggers p27Kip1 degradation independently of CDK2/cyclin E in NIH 3T3 cells. J Biol Chem 276: $34958-34965$

Dubik D, Shiu RP (1992) Mechanism of estrogen activation of c-myc oncogene expression. Oncogene 7: 1587-1594

Dyson N (1998) The regulation of E2F by pRB-family proteins. Genes Dev 12: $2245-2262$

Elston CW, Ellis IO (1991) Pathological prognostic factors in breast cancer. I. The value of histological grade in breast cancer: experience from a large study with long-term follow-up. Histopathology 19: 403-410

Gaben AM, Saucier C, Bedin M, Redeuilh G, Mester J (2004) Mitogenic activity of estrogens in human breast cancer cells does not rely on direct induction of mitogen-activated protein kinase/extracellularly regulated kinase or phosphatidylinositol 3-kinase. Mol Endocrinol 18: 2700-2713

Gaskell DJ, Hawkins RA, de Carteret S, Chetty U, Sangster K, Forrest AP (1992) Indications for primary tamoxifen therapy in elderly women with breast cancer. Br J Surg 79: 1317-1320

Gaubatz S, Lindeman GJ, Ishida S, Jakoi L, Nevins JR, Livingston DM, Rempel RE (2000) E2F4 and E2F5 play an essential role in pocket protein-mediated G1 control. Mol Cell 6: 729-735

Ginsberg D, Vairo G, Chittenden T, Xiao ZX, Xu G, Wydner KL, DeCaprio JA, Lawrence JB, Livingston DM (1994) E2F-4, a new member of the E2F transcription factor family, interacts with p107. Genes Dev 8: $2665-2679$

Goldhirsch A, Wood WC, Gelber RD, Coates AS, Thurlimann B, Senn HJ (2007) Progress and promise: highlights of the international expert consensus on the primary therapy of early breast cancer 2007. Ann Oncol 18: $1133-1144$

\section{Conflict of interest}

The authors do not have any conflict of interest in performing this study that could have biased the design of the experiments or the analysis of the results.

Supplementary Information accompanies the paper on British Journal of Cancer website (http://www.nature.com/bjc)
Helin K, Lees JA, Vidal M, Dyson N, Harlow E, Fattaey A (1992) A cDNA encoding a pRB-binding protein with properties of the transcription factor E2F. Cell 70: $337-350$

Hijmans EM, Voorhoeve PM, Beijersbergen RL, van ' $t$ Veer LJ, Bernards R (1995) E2F-5, a new E2F family member that interacts with p130 in vivo. Mol Cell Biol 15: 3082-3089

Ivey-Hoyle M, Conroy R, Huber HE, Goodhart PJ, Oliff A, Heimbrook DC (1993) Cloning and characterization of E2F-2, a novel protein with the biochemical properties of transcription factor E2F. Mol Cell Biol 13: $7802-7812$

Kaelin Jr WG, Sellers WR, DeCaprio JA, Ajchenbaum F, Fuchs CS, Chittenden T, Li Y, Farnham PJ, Blanar MA, Liveingston DM, Flemington EK (1992) Expression cloning of a cDNA encoding a retinoblastoma-binding protein with E2F-like properties. Cell 70: $351-364$

Kowalik TF, DeGregori J, Schwarz JK, Nevins JR (1995) E2F1 overexpression in quiescent fibroblasts leads to induction of cellular DNA synthesis and apoptosis. J Virol 69: $2491-2500$

La Thangue NB, Rigby PW (1987) An adenovirus E1A-like transcription factor is regulated during the differentiation of murine embryonal carcinoma stem cells. Cell 49: 507-513

Lees JA, Saito M, Vidal M, Valentine M, Look T, Harlow E, Dyson N, Helin K (1993) The retinoblastoma protein binds to a family of E2F transcription factors. Mol Cell Biol 13: 7813-7825

Lindeman GJ, Dagnino L, Gaubatz S, Xu Y, Bronson RT, Warren HB, Livingston DM (1998) A specific, nonproliferative role for E2F-5 in choroid plexus function revealed by gene targeting. Genes Dev 12: $1092-1098$

Livasy CA, Karaca G, Nanda R, Tretiakova MS, Olopade OI, Moore DT, Perou CM (2006) Phenotypic evaluation of the basal-like subtype of invasive breast carcinoma. Mod Pathol 19: 264-271

Lukas J, Herzinger T, Hansen K, Moroni MC, Resnitzky D, Helin K, Reed SI, Bartek J (1997) Cyclin E-induced S phase without activation of the pRb/E2F pathway. Genes Dev 11: 1479-1492

Macaluso M, Cinti C, Russo G, Russo A, Giordano A (2003) pRb2/p130-E2F4/ 5-HDAC1-SUV39H1-p300 and pRb2/p130-E2F4/5-HDAC1-SUV39H1DNMT1 multimolecular complexes mediate the transcription of estrogen receptor-alpha in breast cancer. Oncogene 22: $3511-3517$

Medema RH, Kops GJ, Bos JL, Burgering BM (2000) AFX-like Forkhead transcription factors mediate cell-cycle regulation by Ras and PKB through p27kip1. Nature 404: 782-787

Morkel M, Wenkel J, Bannister AJ, Kouzarides T, Hagemeier C (1997) An E2F-like repressor of transcription. Nature 390: 567-568

Navolanic PM, Steelman LS, McCubrey JA (2003) EGFR family signaling and its association with breast cancer development and resistance to chemotherapy (Review). Int J Oncol 22: 237-252

Paik S, Bryant J, Park C, Fisher B, Tan-Chiu E, Hyams D, Fisher ER, Lippman ME, Wickerham DL, Wolmark N (1998) erbB-2 and response to doxorubicin in patients with axillary lymph nodepositive, hormone receptor-negative breast cancer. J Natl Cancer Inst 90: $1361-1370$

Polanowska J, Le Cam L, Orsetti B, Valles H, Fabbrizio E, Fajas L, Taviaux S, Theillet C, Sardet C (2000) Human E2F5 gene is oncogenic in primary rodent cells and is amplified in human breast tumors. Genes Chromosomes Cancer 28: 126-130

Rakha EA, El-Sayed ME, Green AR, Lee AH, Robertson JF, Ellis IO (2007) Prognostic markers in triple-negative breast cancer. Cancer 109: 25-32

Ross JS, Fletcher JA, Bloom KJ, Linette GP, Stec J, Symmans WF, Pusztai L, Hortobagyi GN (2004) Targeted therapy in breast cancer: the HER-2/neu gene and protein. Mol Cell Proteomics 3: 379-398 
Sabbah M, Courilleau D, Mester J, Redeuilh G (1999) Estrogen induction of the cyclin D1 promoter: involvement of a cAMP response-like element. Proc Natl Acad Sci USA 96: 11217-11222

Sardet C, Vidal M, Cobrinik D, Geng Y, Onufryk C, Chen A, Weinberg RA (1995) E2F-4 and E2F-5, two members of the E2F family, are expressed in the early phases of the cell cycle. Proc Natl Acad Sci USA 92: 2403-2407

Shan B, Zhu X, Chen PL, Durfee T, Yang Y, Sharp D, Lee WH (1992) Molecular cloning of cellular genes encoding retinoblastoma-associated proteins: identification of a gene with properties of the transcription factor E2F. Mol Cell Biol 12: 5620-5631

Slamon DJ, Clark GM, Wong SG, Levin WJ, Ullrich A, McGuire WL (1987) Human breast cancer: correlation of relapse and survival with amplification of the HER-2/neu oncogene. Science 235: 177-182

Slamon DJ, Leyland-Jones B, Shak S, Fuchs H, Paton V, Bajamonde A, Fleming T, Eiermann W, Wolter J, Pegram M, Baselga J, Norton L (2001) Use of chemotherapy plus a monoclonal antibody against HER2 for metastatic breast cancer that overexpresses HER2. N Engl J Med 344: 783-792

Sorlie T, Perou CM, Tibshirani R, Aas T, Geisler S, Johnsen H, Hastie T, Eisen MB, van de Rijn M, Jeffrey SS, Thorsen T, Quist H, Matese JC, Brown PO, Botstein D, Eystein Lonning P, Borresen-Dale AL (2001) Gene expression patterns of breast carcinomas distinguish tumor subclasses with clinical implications. Proc Natl Acad Sci USA 98: 10869-10874

Sorlie T, Tibshirani R, Parker J, Hastie T, Marron JS, Nobel A, Deng S, Johnsen H, Pesich R, Geisler S, Demeter J, Perou CM, Lonning PE, Brown PO, Borresen-Dale AL, Botstein D (2003) Repeated observation of breast tumor subtypes in independent gene expression data sets. Proc Natl Acad Sci USA 100: $8418-8423$
Tavassoli A, Devilee P (eds). (2003) Pathology \& Genetics Tumours of the Breast and Female Genital Organs. International Agency for Research on Cancer Press: Lyon

Trimarchi JM, Fairchild B, Verona R, Moberg K, Andon N, Lees JA (1998) E2F-6, a member of the E2F family that can behave as a transcriptional repressor. Proc Natl Acad Sci USA 95: 2850-2855

Trimarchi JM, Lees JA (2002) Sibling rivalry in the E2F family. Nat Rev Mol Cell Biol 3: $11-20$

Verona R, Moberg K, Estes S, Starz M, Vernon JP, Lees JA (1997) E2F activity is regulated by cell cycle-dependent changes in subcellular localization. Mol Cell Biol 17: 7268-7282

Vogel CL, Cobleigh MA, Tripathy D, Gutheil JC, Harris LN, Fehrenbacher L, Slamon DJ, Murphy M, Novotny WF, Burchmore M, Shak S, Stewart SJ, Press M (2002) Efficacy and safety of trastuzumab as a single agent in first-line treatment of HER2-overexpressing metastatic breast cancer. J Clin Oncol 20: 719-726

Weisz A, Rosales R (1990) Identification of an estrogen response element upstream of the human $\mathrm{c}$-fos gene that binds the estrogen receptor and the AP-1 transcription factor. Nucleic Acids Res 18: 5097-5106

(c) $($ (1) $\rightleftharpoons$ This work is licensed under the Creative Commons CC. $\mathrm{BY}$ NC ND Attribution-NonCommercial-NoDerivs 3.0 License. To view a copy of this license, visit http://creativecommons.org/ licenses/by-nc-nd/3.0/. 